\title{
Historia i pamięć w biblijno-liturgicznym przekazie katechetycznym w koncepcji Sofii Cavalletti
}

Koncepcja wychowania religijnego stworzona w 1954 roku przez Sofię Cavalletti (1917-2011) i Giannę Gobbi (1919-2002) realizowana jest obecnie na całym świecie. Głównym przesłaniem La Catechesi del buon Pastore (Katecheza Dobrego Pasterza) jest głoszenie urzeczywistniania się przymierza Boga z ludźmi w Osobie Jezusa Chrystusa dobrego Pasterza ${ }^{1}$. Dzieci od najmłodszych lat wprowadzane są w język liturgiczny, który pomaga w świadomym uczestnictwie we mszy świętej, będącej źródłem życia duchowego każdego katolika. Refleksja nad słowem Bożym, życie nim w liturgii oraz pochylenie się nad tajemnicą dziecka stanowią trzy fundamentalne aspekty tejże koncepcji. Można ją umiejscowić w ruchu kerygmatycznym z czasów katechezy wczesnochrześcijańskiej ubogaconej egzegezą biblijną oraz zmodyfikowanymi przesłankami antropologicznymi.

Metoda znaku, na której opiera się praca katechetyczna z dziećmi najmłodszymi (odczytywanie znaków liturgicznych i biblijnych), jest również podstawą przekazu historii biblijnej dla dzieci starszych. Wprowadzane są one w rozumienie historii zbawienia w kontekście uobecniania się jej w liturgii rozumianej jako pamiątka.

Celem artykułu jest przybliżenie podstaw biblijno-liturgicznych Katechezy Dobrego Pasterza realizowanych w pracy z dziećmi między

${ }^{1}$ Inne artykuły przybliżające tę koncepcję: B. Surma, Formacja religijna dziecka a rola dorosłego w koncepcji pedagogicznej Marii Montessori na przykładzie „Katechezy Dobrego Pasterza” Sofii Cavalletti, „Paedagogia Christiana” 23 (2009) nr 1, s. 147-157; taż, Pedagogika Montessori-podstawy teoretyczne itwórcze inspiracje w praktyce, Łódź 2008 oraz Pedagogika Marii Montessori w Polsce i na świecie, pod red. B. Surmy, Łódź 2009. 
szóstym a dwunastym rokiem życia. W pierwszej kolejności zostanie uzasadniony wybór metody znaku w kontekście rozumienia historii w tradycji judeochrześcijańskiej oraz przekazu biblijno-liturgicznego, a następnie przybliżona będzie myśl Cavalletti na temat znaku-wydarzenia, znaku-osoby, znaku-typu, które dotyczą realizacji treści związanej $\mathrm{z}$ historią i pamięcią.

\section{Historia w tradycji judeochrześcijańskiej}

Dziecko od trzeciego roku życia wprowadzane jest czynnie w nawiązywanie „zażyłości” z Osobowym Bogiem. Dopiero w późniejszym czasie, po szóstym roku życia, zgodnie z możliwościami poznawczymi dziecko wprowadzane jest w świat wydarzeń historii zbawienia i odkrywanie Boga jako tego, który daje człowiekowi świat, drugiego człowieka, siebie samego w Osobie Jezusa i zapowiada Jego powtórne przyjście na końcu czasów. Charakterystyczne w tej koncepcji jest przedstawianie historii zbawienia w całościowym ujęciu, tj. od stworzenia świata poprzez odkupienie aż do paruzji. W praktyce dzieci odczytują wybrane fragmenty z Pisma Świętego, opisujące dane wydarzenie w Starym Testamencie (np. stworzenie, grzech pierworodny, potop, Abraham, Mojżeszi wyjście). Następnie porównują je z tekstami z Nowego Testamentu ukazującymi te wydarzenia-typy lub osoby-typy w kontekście odkupienia. Kolejnym krokiem różniącym typologię stosowaną przez Cavalletti od tej tradycyjnie rozumianej jest konfrontacja tychże tekstów (wydarzenia starotestamentowe i Odkupienie) z proroctwami zapowiadającymi, czym będzie na przykład nowe stworzenie w paruzji, oraz z tekstami liturgicznymi.

Podkreślany przez Cavalletti ścisły związek między Biblią a liturgią wyrażany jest w jedności stosowanej metody. Typologia i „pamiątka”, czyli sposób przeżywania historii zbawienia, używają tych samych terminów. Dotyczą tych samych trzech wymiarów czasu: przeszłości i antycypacji przyszłości w celebracji „dzisiaj”. W związku z tym zarówno typologia, jak i pamiątka są uwolnione od granic czasowych i przestrzennych i niosą główne przesłanie katechezy².

${ }^{2}$ Por. S. Cavalletti, Potencjał duchowy dziecka w wieku od 6 do 12 lat. Opis doświadczenia, przekł. K. Stopa, Kraków 2003, s. 112. 
Te trzy momenty wskazują na jedność historii zbawienia, która została spisana w jedynej księdze, jaką jest Biblia, i na jednego Autora, jakim jest Bóg, który dla człowieka i z nim współtworzy tę historię. Idea odczytywania wydarzeń zbawczych realizujących się w czasie wynika, jak pisze Cavalletti, z tradycji żydowskiej i chrześcijańskiej, posługującej się typologią biblijną rozumianą jako specyficzna metoda interpretacji wydarzeń historii zbawienia ${ }^{3}$. Ta typologiczna interpretacja wydarzeń, znaków, osób Starego Testamentu polega na odczytywaniu ich w świetle Bożego planu zbawienia. Stanowią one typy, wyobrażenia symboliczne rzeczywistości Nowego Przymierza ${ }^{4}$. W semickiej interpretacji historii, która została przejęta przez chrześcijan, biblijne wydarzenia pozwalają na poznanie Boga.

Na czym polegało to semickie podejście do historii? Wyjaśnienie znajduje się w odmiennym rozumieniu dziejów przez Greków i Semitów. Grecy uważali, że proces dziejowy przebiega cyklicznie, i w historii nie dostrzegali żadnego sensu, nie zmierzała ona do celu i ostatecznego wypełnienia, wszystko się powtarzało. Natomiast w myśli semickiej, wyrażonej w Biblii, w świecie wszystko podlegało ciągłej zmianie i ewolucji. Jak podaje Franciszek Szulc, ,,najgłębszym źródłem istnienia całej rzeczywistości stworzonej jest Bóg. Jego suwerennej władzy wszystko podlega i On wszystkim kieruje, ustanawia prawo i je zmienia. To, co zmienne i będące w ruchu, jest jednocześnie czymś najbardziej realnym, bo objawia potęgę Stworzyciela i ujawnia Jego plan działania" ${ }^{5}$. Historia zbawienia ma ściśle określony początek i przebiega wedle Bożego zamysłu, by osiągnąć swój cel w paruzji. Zatem linearna koncepcja procesu dziejowego sprzeciwia się cyklicznemu rozumieniu historii przez Greków. Wydarzenia i znaki, których dokonał i dokonuje Bóg, nie wyczerpują swojego znaczenia, ale prowadzą w kierunku transcendencji.

Cavalletti podaje, że w teologii biblijnej celem historii zbawienia jest przymierze: „termin teologiczny, który w potocznym języku wyraża nie

${ }^{3}$ Szerzej wyjaśnia to F. Szulc, Struktura teologii judeochrześcijańskiej, Kraków 2005, s. 104-140; zob. też J. Daniélou, Teologia judeochrześcijańska, przekł. S. Basista, Kraków 2002 (Myśl Teologiczna, 39); B. Poniży, Motyw Wyjścia w Biblii. Od historii do teologii, Poznań 2001 (Biblioteka Pomocy Naukowych, 21).

${ }^{4}$ Por. F. Szulc, Struktura teologii judeochrześcijańskiej, dz. cyt., s. 113.

${ }^{5}$ Tamże, s. 135. 
tylko relację, nie tylko związek między dwoma kontrahentami, ale, jak mówią prorocy, chodzi o relację pokoju - Berit shalom". Przymierze stanowi religijny fakt, który ma miejsce także w naszej rzeczywistości, tu i teraz. Jest fundamentalnym pojęciem w Biblii i wskazuje na istotę wychowania religijnego. Autorka dodaje, że przymierze pokoju, „berit jest uniwersalną harmonią, która pochodzi od jedynego Boga, Osobowego, Pana historii, łączącą wszystkie poziomy stworzenia"7. Częściowo dokonuje się to podczas Eucharystii, kiedy Chrystus jednoczy nas z Bogiem w komunii, dzięki owocom ludzkiej pracy i darom stworzonym przez Boga Ojca.

Analizując treści katechez w koncepcji Cavalletti dla dzieci powyżej szóstego roku życia, można stwierdzić, że historia i pamięć stanowią dwa fundamentalne zagadnienia realizowane przez wychowanie biblijne - typologię i wychowanie liturgiczne - metodę znaków polegającą na odczytywaniu ich znaczenia, w tym także znaczenia wydarzeń biblijnych, w kontekście teraźniejszości, uobecniania się ich w życiu współczesnego człowieka. Dziecko wprowadzane jest stopniowo w transcendentny wymiar historii, rozpoczynając od znaków liturgicznych poprzez przypowieści, by na końcu dzięki typologii móc odczytywać teologię zbawienia.

\section{Metoda znaku w przekazie biblijno-liturgicznym}

Wybór metody znaku Cavalletti tłumaczy powrotem do nauczania, które przez całe wieki pozostawało żywe, do nauczania, na którym opiera się życie Kościoła, czyli do liturgii ${ }^{8}$. Autorka ściśle łączy wprowadzanie w liturgię z głoszeniem Biblii i na odwrót. Uważa, że „w świecie biblijnym liturgia zajmuje bardzo ważne miejsce. Konieczne jest więc wprowadzenie w nią dzieci, by orędzie zachowało całe swe bogactwo. Biblia trafia w niektóre istotne punkty ludzkiego życia, przekazując nam odnoszące się do nich przesłanie. Jednak Biblia nie jest księgą statyczną. Już od swych początków była ona żywą księgą w życiu wierzących

\footnotetext{
${ }^{6}$ S. Cavalletti, Semi di pace, „Vita dell’infanzia” 12 (1971), s. 8 (tłum. własne).

${ }^{7}$ Tamże, s. 8.

${ }^{8}$ Por. C. Vagaggini, Il senso teologico della liturgia, Roma 1958, s. 33; zob. S. Cavalletti, Appunti di liturgia, Rzym 1990, pro-manuskrypt (tłum. własne).
} 
oraz cywilizacji zachodniej"9. W liturgii Boże Objawienie staje się dla człowieka istotne i żywe: ,w ciągu długiego rozwoju historii zbawienia, w pewnym określonym momencie, rzeczywiście i my w nią weszliśmy. Od tego momentu Biblia stała się dla nas księgą, która zawiera prehistorię i historię każdego z nas, a liturgia jest najszczególniejszym środkiem dla zaktualizowania jej w naszym życiu"10.

Celebracja liturgiczna nadaje konkretności wydarzeniom zbawczym, a także umożliwia wszystkim przyszłym pokoleniom „przeżywanie w dalszym ciągu nowości, której są nosicielami" ${ }^{11}$. Poprzez widzialne znaki dokonuje się celebracja wydarzeń, w których Bóg się objawił, czyli świętowanie spotkania człowieka z Bogiem. Człowiek potrzebuje takich momentów, które można nazwać „kondensacją” spotkania. Ich istotą jest nawiązywanie więzi, wyrażanie relacji z Bogiem, rozpalanie i wzbogacanie jej, bowiem bez tych momentów istnieje ryzyko osłabnięcia wiary ${ }^{12}$.

Proponowana przez Cavalletti metoda znaku prowadzi w kierunku odczytywania znaków liturgicznych w sensie historiozbawczym i antropologicznym. Historia zbawienia przekazywana jest dzieciom jako ciąg wydarzeń, przez które Bóg dokonuje zbawienia człowieka. Opiera się ona na relacji-przymierzu pomiędzy Bogiem a człowiekiem, który od momentu grzechu pierworodnego zerwał pokojową relację, a Bóg na przestrzeni dziejów nieustannie dąży do jej odnowienia. Punktem centralnym jest Chrystus, znak Boga pośród ludzi. Historia zbawienia dokonuje się ciągle i realnie, a dzieło odkupienia obejmuje całościowo czas ziemski ${ }^{13}$.

W tak przedstawianej historii zbawienia istotne jest rozumienie liturgii jako wyjścia Boga do człowieka, jak zauważa Romano Guardini: „na początku stoi nie wysiłek jednego religijnego człowieka, w czasie którego otrzymuje on oświecenie, ale Boże działanie. To działanie jest pierwszym podstawowym objawieniem: Bóg jest tym, który może działać i rzeczywiście działa. Jego działanie wprowadza w tok historię, działa w niej, prowadzi ją i tłumaczy, napomina i karze" ${ }^{14}$. Podobne ujęcie li-

\footnotetext{
${ }^{9}$ S. Cavalletti, Potencjał duchowy dziecka..., dz. cyt., s. 102-103.

${ }^{10}$ Taż, La storia della salvezza, Roma 1995, s. 23.

${ }^{11}$ Taż, Potencjał duchowy dziecka..., dz. cyt., s. 109

12 Por. tamże, s. 102-103.

${ }^{13}$ Por. tamże, s. 109.

${ }^{14}$ R. Guardini, Objawienie: natura i formy objawienia, tł. A. Paygert, Warszawa 1957, s. 81.
} 
turgii przedstawia Michael Kunzler, który nazywa ją Służbą Bożą, czyli „komunikacją między Bogiem i rodzajem ludzkim”. I dalej wyjaśnia: „Tutaj właśnie wysuwa się na czoło wymiar katabatyczny, który umożliwia ze swej strony wymiar anabatyczny: Bóg występuje z inicjatywą przebóstwienia człowieka i świata, a ta inicjatywa dochodzi do głosu w Jego Służbie, w służbie Boga światu; podczas Liturgii dokonuje się zstępowanie (katabasis) Boga na świat w celu zrealizowania życiodajnej i przebóstwiającej wymiany"15.

Bóg stopniowo poprzez działanie dla człowieka i z człowiekiem objawia siebie. Na początku była to zapowiedź przyjścia Mesjasza, następnie jej realizacja, a teraz aktualizacja aż do całkowitego wypełnienia dzieła. Ponieważ człowiek jako istota ziemska nie jest zdolny w pełni pojąć tej rzeczywistości, dlatego może się ona stać dla niego dostępna tylko poprzez znaki i symbole.

Wymiar antropologiczny metody znaku można dostrzec w wyjaśnieniach liturgistów. Marian Rusecki pisze, że „objawienie Boże w historii zbawienia realizuje się w znakach, gdyż inaczej nie mogłoby ono być dostępne dla percepcji ludzkiej. Właśnie Jezus Chrystus jako wcielony i „uhistoryczniony” Syn Boży w ludzkiej naturze stał się znakiem Boga. Jego natura stała się nośnikiem bóstwa, wkraczającego w historię i w dzieje ludzkości”" ${ }^{16}$. Natomiast według Salvatore Marsiliego „człowiek stwarza znak, aby zapamiętać interwencję Boga i uwiecznić pamięć Jego odwiecznego i konkretnego działania nie tylko dla siebie samego, lecz również dla tych, którzy żyć będą po nim. Jego zdaniem istotnym momentem dla zrozumienia genezy i istoty znaku, który zawsze prowokuje i wywołuje określoną reakcję człowieka, a mając charakter responsoryjny, zakłada odpowiedź człowieka"17.

Ontologicznie znak tworzą dwie strony: „Bóg przezznak komunikujący wolę zbawczą oraz człowiek przez znak upamiętniający interwencję Boga ina nią odpowiadający. Znak więcjest miejscem spotkania mówiącego Boga i odpowiadającego człowieka - miejscem dialogu. Znak bowiem, jeśli nie przemawia, nie jest znakiem, gdy zaś przemawia, wymaga odpowiedzi" ${ }^{18}$.

\footnotetext{
${ }^{15}$ M. Kunzler, Liturgia Kościoła, przekł. i oprac. L. Balter, Poznań 1999, t. 10, s. 30.

${ }^{16}$ M. Rusecki, Bóg objawiający sięw dziełach, „Ateneum Kapłańskie” 118 (1992) z. 3, s. 452.

${ }^{17}$ Cyt. za: B. Migut, Znaki Misterium Chrystusa, Lublin 1996, s. 40.

${ }^{18}$ Tamże, s. 40.
} 
Realizacja tych założeń w Katechezie Dobrego Pasterza zaczyna się w momencie głoszenia trzyletniemu dziecku Boga, który objawił się jako Słowo Wcielone ${ }^{19}$. Następnie prowadzone jest, by mogło w pełni i świadomie spotkać z się z Nim. Głoszenie kerygmatu początkowo przygotowuje je do słuchania, które ma wywoływać w nim zachwyt, zdumienie. Po tym pierwszym etapie następuje moment, w którym dziecko udziela odpowiedzi Bogu poprzez osobistą modlitwę, przyjęcie Go w sakramentach, a następnie w czynie, w codziennym życiu.

Metoda znaków jest drogą, przez którą uczeń musi przejść, by doświadczyć, przeżyć, przemyśleć i w ostateczności przyjąć albo odrzucić rzeczywistość, którą mógł namacalnie poznać, a nie tylko intelektualnie, czyli w praktyce pamięciowo przyswoić. Cavalletti wyjaśnia, że „religia biblijna jest religią Boga niepoznawalnego i transcendentnego, który się objawia. Ta pozorna sprzeczność znajduje swe rozwiązanie w zna$\mathrm{ku}^{\prime 20}$. Przez znak dochodzi się do poznania tego, co kryje się za znakiem. Zdaniem Cavalletti religijna wartość metody znaków pozwala na „głoszenie Chrystusa tym, którzy nie mają jeszcze żadnej idei Boga". Uważa, że „aby dojść do tego, co transcendentne, nie można pominąć znaków, zaś największym znakiem Ojca jest Chrystus-Emmanuel. W pewien sposób znaki przedłużają w czasie Jego wcielenie, a każdy z nich pochodzi od Chrystusa - pierwotnego znaku, i od Niego czerpie swe znaczenie". Ponieważ „Znak ze swej natury nie pozwala jednak zatrzymać się w obrębie świata postrzegalnego zmysłami, otwiera człowieka na to, co transcendentne. Staje się zatem narzędziem wychowania do wiary, jeśli wiarę rozumie sięjako sposób poznania, który przekracza to, co postrzegalne zmysłami. Poprzez znaki człowiek uczy się nie zatrzymywać na tym, co widzą jego oczy i czego dotykają jego ręce, uczy się szukać na horyzoncie jakiejś innej rzeczywistości. Wprowadzenie do języka znaków daje człowiekowi pewnego rodzaju wewnętrzną sprawnośc" ${ }^{21}$. Małe dziecko nie tylko rozumie świat znaków, ale tymi znakami żyje (można tu przytoczyć obraz niemowlaków, które potrafią odczytać

${ }^{19}$ Szczegółowy program i realizacja zob. B. Surma, K. Biel, Jajestem dobrym Pasterzem. Przewodnik metodyczny do katechezy Dobrego Pasterza dla dzieci od trzeciego do piatego roku życia, Łódź 2011.

${ }^{20}$ S. Cavalletti, Potencjał duchowy dziecka..., dz. cyt., s. 204.

${ }^{21}$ Tamże, s. 214-215. 
nastrój rodziców, przede wszystkim matki, jej mimikę, odpowiadają pierwszym uśmiechem, rozpoznają twarze, oraz dzieci, które zaczynają rozumieć i posługiwać się mową, czyli znakami słownymi) ${ }^{22}$.

Ponadto dziecko w pierwszym okresie życia poznaje świat wszystkimi swoimi zmysłami, a „znak wiąże się ze światem zmysłowym, a zarazem pobudza, by dotrzeć do Niewidzialnego. Zdolność percepcyjna człowieka rozszerza się i pogłębia, staje się on zdolny widzieć poza powierzchownością. W znaku świat materialny zyskuje pewnego rodzaju przejrzystość, a świat transcendentny namacalność"23. Wykorzystując naturalną zdolność dziecka do spostrzegania zmysłami, powinno się je prowadzić drogą znaków do wiary. Jak wynotował Tarsycjusz Sinka, „Tomasz z Akwinu (zm. 1274) powiada, że Mądrość Boża troszczy się o każdy byt zgodnie z jego naturą. Jest więc rzeczą odpowiednią, aby człowiek jako istota cielesno-duchowa, poprzez znaki widzialne, cielesne, docierał do rzeczywistości duchowej"24.

A Michael Kunzler ukazuje, że odrzucenie świata zmysłowego kwestionowałoby łączność Boga ze stworzeniem, na której opiera się liturgia. „W czasowo-przestrzennych wymiarach naszego świata komunikowanie się osób jest możliwe tylko wtedy, gdy istnieje jakieś mi ędzy, które umożliwia komunikującym się ze sobą partnerom wzajemną ich o be c n ość. Tym międ zy jest przede wszystkim cielesność człowieka, za pomocą której musi się wyrażać na zewnątrz, gdy chce wejść w relację z kimś innym"25. Jego zdaniem dokonuje się to dzięki uzewnętrznianiu się duchowego jądra osoby z cielesnego mi ę d zy konkretnego odniesienia. Sugeruje również, że „gratia supponit naturam: bez natury nie ma łaski, nie ma bowiem żadnej płaszczyzny komunikacji dla osobowego odniesienia między Bogiem a człowiekiem, a tym samym nie ma też spotkania”. Dalej tłumaczy, że „samo stworzenie jako świat dostępny zmysłom, myśleniu, czuciu i pojmowaniu człowieka stanowi to międ zy osobowego odniesienia Boga i człowieka. Jako stworzenie, człowiek należy także do świata stworzonego; jako ucieleśniona istota duchowa wznosi się jednak ponad

${ }^{22}$ Według R. Guardiniego, Objawienie..., dz. cyt., s. 65, „mowa jest związkiem symboli, do którego jednostka wnika zaraz po urodzeniu, jest formą bytu, ogarniającą człowieka".

${ }^{23}$ S. Cavalletti, Potencjał duchowy dziecka..., dz. cyt., s. 204.

${ }^{24}$ T. Sinka, Zarys liturgiki, Kraków 1997, s. 75.

${ }^{25}$ M. Kunzler, Liturgia Kościoła, dz. cyt., s. 44. 
ten świat i posługuje się nim jako niższą od siebie płaszczyzną komunikowania w swych międzyludzkich, osobowych odniesieniach" ${ }^{26}$.

Ponadto trzeba dodać, że metoda znaku nawiązuje do nauczania wielkich ojców Kościoła, którzy posługiwali się właśnie metodą obrazową ${ }^{27}$. Zdaniem Theodora Schneidera ,antyczne rozumienie obrazu polega na sposobie przekazywania tego, co jest odwzorowywane, a nie, że jest tylko zwykłym wskazywaniem na coś innego. Przez Jezusa doświadcza się, kim jest Bóg i jaki jest Bóg. "On jest ob ra ze m B og a ", jak mówi św. Paweł (2 Kor 4, 4)”"28. A jak twierdzi Dorothea Forstner, „dla ludzi obraz jest drogą do prawzoru. Każda rzecz podpada pod zmysły, w której wieczna idea łączy się z przemijającą materią, wskazuje na to, co wieczne i w ten sposób staje się symbolem w znaczeniu pierwotnym; oraz z nim dana jest nam owa p oł o w a która odpowiada drugiej i tworzy z nią całość" 29 .

Salvatore Marsili dodaje, że ,teologia liturgiczna jest teologią obecności i działania Bożego w historii zbawienia, teologią żywą, uwzględniającą konkretne, tu i teraz uobecnione wydarzenie zbawcze w odniesieniu do centralnej rzeczywistości całej historii, którą jest Chrystus i Jego Kościół" ${ }^{30}$. Podobne rozumienie liturgii i historii jako celebrowania spotkania człowieka z Chrystusem tu i teraz spotykamy w koncepcji katechetycznej Cavalletti, co wyrażone jest doborem treści i metody, a także ściśle koresponduje z postulatami wyrażonymi przez Kongregacje do spraw Wychowania na temat katechezy biblijno-liturgicznej.

\section{Znak w koncepcji judeochrześciajńskiej}

Głównymi źródłami, na których autorka opiera swoje rozważania na temat znaku, są Biblia i Tradycja. Jedną z myśli zawartych w Piśmie Świętym jest próba opowiedzenia tego, kim jest Bóg. W jaki sposób człowiek, który jest ograniczony, może poznać Boga nieograniczonego? Na to

${ }^{26}$ Tamże, s. 47.

${ }^{27}$ Por. S. Cavalletti, Potencjat duchowy dziecka..., dz. cyt., s. 202-203.

${ }^{28}$ T. Schneider, Znaki bliskości Boga. Zarys sakramentologii, tł. J. Tyrawa, Wrocław 1990, s. 32.

${ }^{29}$ D. Forstner, Świat symboliki chrześcijańskiej, przekł. i oprac. W. Zakrzewska, Warszawa 1990, s. 7.

${ }^{30}$ Cyt. za: B. Migut, Znaki Misterium Chrystusa, dz. cyt., s. 24. 
pytanie odpowiada Biblia (Mdr 13,1-3), ale nie tylko. Jak podaje Cavalletti, według starożytnej tradycji hebrajskiej (midrasz) Bóg miał odpowiedzieć Mojżeszowi, który prosił Go, by ujawnił mu Imię (,imię” ewidentnie oznacza wewnętrzną istotę Bożej natury): „Mojego Imienia nie możesz poznać; moje Imięjest zgodne z moimi dziełami” ${ }^{31}$. A zatem poznanie Boga niepoznawalnego jest możliwe dzięki Jego dziełom, które są Jego objawieniem, czyli Jego znakiem. O Bożych dziełach można opowiadać. Jednak istnieje niebezpieczeństwo „rozczłonkowania na wiele różnych historyjek jednej wielkiej historii, którą Bóg tworzy z ludzkością. Skutkiem tego historia traci wartość tajemnicy, a jej ładunek moralny słabnie"32. Wyjściem jest stałe odniesienie pojedynczego wydarzenia do całości historii zbawienia, które realizowane jest w koncepcji Katechezy Dobrego Pasterza.

W religii żydowskiej i chrześcijańskiej znak jest przede wszystkim dziełem, wydarzeniem, faktem, na ile wyraża dobrą wolę ze strony Boga. Dobra wola w momencie, kiedy pojawił się grzech pierworodny w świecie, zamienia się w wolę zbawienia. Hebraizm i chrześcijaństwo są religiami historycznymi i dlatego pierwszą charakterystyczną cechą znaku - według Cavalletti - jest jego charakter historyczny ${ }^{33}$.

Autorka podkreśla, że „Bóg, którego nie można zobaczyć i pozostać żywym, wchodzi w dialog z człowiekiem. Można powiedzieć, że gdzie jest duchowość biblijna, tam jest dialog z Bogiem, z tym Bogiem, którego żaden hebrajczyk nie może przedstawiać obrazem, a nawet wymieniać Jego imienia. Ta pozorna sprzeczność znajduje rozwiązanie w znaku. Boga nieograniczonego, niepoznawalnego, którego właściwości można rozpoznać tylko w świecie, porównać można do węgla i płomienia: węgiel - jak mówią Żydzi - istnieje również bez płomienia; jest to nieznany świat bez określonych granic. Ukryta moc węgla objawia się dopiero dzięki płomieniowi. My możemy powiedzieć, że płomień jest znakiem, dzięki któremu można poznać Niepoznawalnego"34.

${ }^{31}$ S. Cavalletti, La carità nella catechesi ai bambini, „Via, verità e vita” 21 (1969) 8, s. 77; por. także taż, Segno, simbolo, tipo nell'ebraismo e nel cristianesimo primitivo, [w:] I segni nella liturgia, Padova 1970, s. 42 (Liturgia. Nova serie, 9).

${ }^{32}$ S. Cavalletti, Potencjał duchowy dziecka..., dz. cyt., s. 54.

${ }^{33}$ Por. tamże, s. 42.

${ }^{34}$ Tamże, s. 41. 
Znakami pierwotnymi są Boże dzieła, których dokonuje w czasie, w historii. Można je nazwać znakami historycznymi. Wśród Bożych dzieł największym objawieniem miłości jest stworzenie człowieka, a między nimi Emmanuela. Emmanuel jest znakiem w najwyższym stopniu i jest również znakiem sui generis, który w rozległym świecie znaków zajmuje oddzielne miejsce. To dzieło ma tak ogromne znaczenie, że jego ciężar został ustalony wcześniej, zanim dokonało się ono w historii człowieka; będąc w myśli Boga, ten czyn odzwierciedla się w historii, przed i po dokonaniu się $e^{35}$.

Wśród znaków historycznych Cavalletti wymienia również znaki-typy. Wiąże to z przyjściem Mesjasza. Tę samą wolę zbawienia, która najbardziej objawia się w znaku Emmanuela, spotyka się, według Tradycji, w ciągu dziejów w uprzywilejowanych ludziach i w określonych wydarzeniach, które zachodzą szczególnie w związku z Emmanuelem. Nie są to jednak znaki tożsame z Nim, jednak będąc znakami samymi w sobie, prowadzą do światła i szczególnego znaczenia Emmanuela i jego przyjścia. Znak jest również typem.

Cavalletti podaje dwa rodzaje znaków-typów: osoba-typ i wydarzenie-typ. Dla wyjaśnienia różnicy między typem a znakiem podaje, że znak otrzymuje światło bezpośrednio z wysoka, podczas gdy typ świeci światłem odbitym, które pochodzi z odbicia wielkiego mesjańskiego znaku ${ }^{36}$.

Dla autorki „znak zatem staje się objawieniem woli dobra, która się zrealizowała i która się realizuje, która jest w toku. Tłumaczy się to faktem, że ta wola nie realizuje się sama. Boże dzieła spełniają się na korzyść człowieka, Bóg spełnia je z człowiekiem, który jest powiązany z czasem. Współpraca człowieka w Bożym dziele wskazuje na drugą charakterystykę biblijnego znaku, która zależy od pierwszej i którą definiuje się jako najistotniejszą: znak biblijny jest tym, czym człowiek żyje, czymś, co bezpośrednio wpływa na jego życie. Człowiek nie jest widzem. Jest aktorem, nawet jeśli jest tylko aktorem drugoplanowym" ${ }^{37}$. Dlatego Cavalletti wyróżnia tu znaki związane z obrzędem. Uważa, że znaki te mają początek

${ }^{35}$ Por. tamże, s. 42-43; por. także S. Cavalletti, Opera unità riparatrice. Educazione religiosa del fanciullo, „Quaderno nr 2”, Roma 1956, cz. V, s. 18-19.

${ }^{36}$ Por. S. Cavalletti, Segno, simbolo, tipo nell'ebraismo e nel cristianesimo primitivo, dz. cyt., s. 43.

${ }^{37}$ Tamże. 
w znakach historycznych, które dokonują się w czasie i w przestrzeni. Dzięki znakom obrzędowym znaki historyczne, czyli objawiające wolę zbawienia stają się aktualne i istotne dla wiernego każdego $\mathrm{czasu}^{38}$.

Znak historyczny dzięki elementom postrzeganym zmysłami staje się możliwością uczestniczenia w akcie zbawienia. Do znaków obrzędowych autorka zalicza modlitwę i sakramenty: „bez tych dwóch środków znak-wydarzenie pozostaje niezrozumiałe dla człowieka; znak rytualny-obrzędowy naświetla znak historyczny"39. Te dwa znaki nie są w bezpośredniej relacji. Znak obrzędowy jest narzędziem znaku historycznego, na ile jest środkiem, dzięki któremu ten drugi uwiecznia się, dając do dyspozycji wolę zbawienia ludziom wszystkich czasów, która została objawiona tylko jeden raz.

Przykładem znaku-wydarzenia jest Pascha, jako znak historyczny staje się wydarzeniem, w którym i my uczestniczymy, ale tylko i wyłącznie dzięki znakom rytualnym, a w szczególności dzięki m e mo riale (zikkaron), czyli pamiątce. Pamiątka jest rzeczywistością obiektywną, faktem, który się realizuje, aktualizuje obiektywnie dziś. Czytamy o tym w Księdze Wyjścia: „Dzień ten (celebracja) będzie dla was dniem pamiętnym i obchodzić go będziecie jako święto dla uczczenia Pana. Po wszystkie pokolenia w tym dniu świętować będziecie zawsze" (Wj 12, 14). Ta zapowiedź dotyczy także nowych pokoleń, które nie uczestniczyły fizycznie w wydarzeniu wyzwolenia spod niewoli egipskiej. Słowa: "Nie zawarł Pan tego przymierza z ojcami naszymi, lecz z nami, którzy tu dzisiaj wszyscy żyjemy" (Pwt 5, 3), wyraźniej pokazują znaczenie pamiątki również w myśli chrześcijańskiej liturgii eucharystycznej. Wydaje się, że pamiątka objawia się nam, jak zauważa Cavalletti, ,jako wolna wobec czasu i przestrzeni, a w celebracji liturgicznej człowiek żyje tą wolnością" ${ }^{40}$. Cavalletti podkreśla również, że pamiątka dotyczy nie tylko przeszłości, która staje się teraźniejszością, ale także przyszłości. Dostrzega zbieżność postrzegania znaków w tradycji hebrajskiej i chrześcijańskiej. W obrzędzie hebrajskim i w chrześcijańskim akt litur-

${ }^{38}$ Por. K. Baran, Eucharystia celebracja paschalnego misterium, Warszawa 1994, s. 65, przypis 58.

${ }^{39}$ S. Cavalletti, Segno, simbolo, tipo nell'ebraismo e nel cristianesimo primitivo, dz. cyt., 50-51, por. także taż, Appunti di liturgia, dz. cyt., s. 26-35.

${ }^{40}$ Taż, Appunti di liturgia, dz. cyt., s. 9. 
giczny (dla przykładu podaje IV modlitwę eucharystyczną) zbudowany jest w ten sam sposób. Składa się ze słów i elementów dostrzegalnych zmysłami podzielonych na trzy momenty: przeszłość, teraźniejszość i przyszłość. Różnice w nich występujące dotyczą wymiaru sakramentalnego i historycznego (oczekiwanie Mesjasza), jednak ich struktura jest podobna, bowiem duchowość znaków obrzędowych w obu tradycjach jest taka sama ${ }^{41}$.

Katechizm Kościoła Katolickiego ${ }^{42}$ podaje, że: „W biblijnym znaczeniu pamiątka nie jest tylko wspominaniem wydarzeń z przeszłości, lecz głoszeniem cudów, jakich Bóg dokonał dla ludzi. W liturgicznej celebracji tych wydarzeń stają się one w pewien sposób obecnie aktualne. Tak właśnie rozumie Izrael swoje uwolnienie z Egiptu; za każdym razem, gdy obchodzi się Paschę, wydarzenia Wyjścia są uobecniane w pamięci wierzących, by według nich kształtowali swoje życie" (KKK 1363). Natomiast „W Nowym Testamencie pamiątka otrzymuje nowe znaczenie. Gdy Kościół celebruje Eucharystię, wspomina Paschę Chrystusa, a ona zostaje uobecniona. Ofiara, którą Chrystus złożył raz na zawsze na krzyżu, pozostaje zawsze aktualna: «Ilekroć na ołtarzu sprawowana jest ofiara krzyżowa, w której 'na Paschę naszą ofiarowany został Chrystus', dokonuje się dzieło odkupienia»” (KKK 1364).

Znaki historyczne dokonują się w czasie i w przestrzeni i dzięki znakom rytualnym człowiek może w nich uczestniczyć i „korzystać” z nich. Znaki historyczne, czyli wydarzenia, przez które Bóg dał się poznać, są podstawą rytu, natomiast znaki nazwane typem nie stanowią jego podstawy, ponieważ stanowią one „odbicie światła”. Modlitwa i sakramenty są środkami, dzięki którym człowiek może spotkać się z Bogiem. W sakramentach takie spotkanie, ,czyli dar łaski ze strony Boga i hołd wiary i miłości ze strony człowieka"43, nabiera kształtu w elementach namacalnych, na których są one zbudowane. Podobną sytuację spotykamy w modlitwie. W sakramencie to Bóg pierwszy przychodzi do nas i przynosi nam swój dar, na który człowiek daje odpowiedź. W modli-

${ }^{41}$ Por. taż, Segno, simbolo, tipo nell'ebraismo e nel cristianesimo primitivo, dz. cyt., s. 53-54; zob. taż, Appunti di liturgia, dz. cyt., s. 12-14.

${ }^{42}$ Katechizm Kościoła Katolickiego, Poznań 1994.

${ }^{43}$ S. Cavalletti, G. Gobbi, Io sono il buon Pastore. Quida per il catechista, I Anno, Roma 1970, s. 37. 
twie Bóg najpierw daje dar słowa, a człowiek na nie odpowiada, jednak za każdym razem tworzy się dialog. Często modlitwę rozumie się jako moment człowieka, ale trzeba zawsze pamiętać o źródle, jakim jest wyjście Boga do człowieka, dzięki któremu można Go poznać. Pokazuje to w sposób wyrazisty cała historia zbawienia.

Pierwszym narzędziem w aktualizacji znaku-wydarzenia historycznego jest modlitwa, jak zauważa Cavalletti, zwłaszcza charakter modlitwy zwanej paradygmatyczną, w której inwokacja poprzedzona jest paradygmatami, czyli głoszeniem faktów z przeszłości, które były znakami woli zbawienia, a o które się błaga, by były skuteczne w tym szczególnym przypadku teraz. Przykładem może tu być żydowska modlitwa paradygmatyczna, którą się odmawiało w okresie pokuty:

Ty, który usłyszałeś Abrahama na Górze Moria, usłyszi wysłuchaj nasze wołanie dzisiaj. Błogosławiony jesteś Ty, Panie, Odkupicielu Izraela.

Ty, który usłyszałeś naszych ojców nad Morzem Czerwonym, usłysz i wysłuchaj nasze wołanie dzisiaj.

Błogosławiony jesteś Panie, który pamiętasz zapomniane rzeczy (Taanith, 2, 4) ${ }^{44}$.

Cavalletti zauważa, że chrześcijanin odwołuje się w swojej modlitwie do głoszenia abstrakcyjnych atrybutów Bożych, natomiast hebrajczyk woli wychwalać konkretne fakty, będące znakiem tychże atrybutów. Modlitwy paradygmatyczne są właściwe dla judaizmu, choć spotyka się je również w liturgii chrześcijańskiej, w której dotyczą życia Chrystusa, ale także wielkich tematów starotestamentowych. Przykładem jest tu modlitwa błogosławieństwa wody chrzcielnej w rycie łacińskim.

Dalej wśród znaków Cavalletti wyróżnia przypowieść, która równocześnie jest oderwana od znaku historycznego, jak i z nim związana. Przypowieść odróżnia się od znaku historycznego, na ile nie zależy od faktu, który rzeczywiście się wydarzył, ale jest z nim związana tą samą metodologią, która polega na zaakcentowaniu tajemnicy bez jej wyjaśniania. Przypowieść jest już znakiem jako słowo, lecz staje się podwójnie znakiem przez fakt, że jest to słowo, które nie mówi wprost, lecz raczej ukrywa i zasłania. Różnica między znakiem a przypowieścią leży jedynie w rodzaju zmysłu, za pomocą którego je percypujemy. „Aby wniknąć w znaczenie przypowieści, musimy pracować wyobraźnią oraz intuicją. Wyobraźnią, ponieważ nie powinniśmy oddalać się od obrazu,

${ }^{44}$ Tłum. własne z języka włoskiego. 
za pośrednictwem którego przypowieść objawia nam daną rzeczywistość. Równocześnie jednak potrzebujemy intuicji, ponieważ poziomy, jakie przypowieść ze sobą zestawia, są nieogarnione. Nie będziemy w stanie uchwycić relacji między nimi inaczej, jak tylko za pomocą intuicji”"45.

\section{Przykłady odczytywania osób jako znaków historycznych i znaków-typów}

Interpretacja typologiczna Starego Testamentu wskazuje między innymi na osoby jako typy Mesjasza. W judaizmie ważną osobą jest postać Abrahama, jest on ojcem dla każdego Żyda i dość wcześnie przypisuje się mu cechy mesjańskie. Poniżej zostanie przedstawione porównanie Abrahama jako znaku-osoby z Narodem Izraelskim, którego dokonała autorka na podstawie tradycji hebrajskiej spisanej w midraszu i tekstach biblijnych. Porównanie to wprowadza w zrozumienie historii zbawienia, a także ukazuje podstawy jej koncepcji katechetycznej dla dzieci powyżej szóstego roku życia.

Podobnie jak Mesjasz, Abraham jest kapłanem, królem i prorokiem. Abraham tworzy królestwo Boże na ziemi. Chodzi tu w szczególności o wykazanie związku, który ustala Tradycja między niektórymi wydarzeniami z życia patriarchy a wydarzeniami z historii Izraela. Nie chodzi o związek przyczynowo-skutkowy, ale o wydarzenia, które w pewnym sensie zaczynają się realizować w życiu Abrahama i odtwarzać w późniejszej historii Izraela. Autorka wymienia i porównuje trzy teksty z Księgi Rodzaju, które odpowiadają pobytowi w Egipcie i Wyjściu ${ }^{46}$. Jej zdaniem teksty te ewidentnie wskazują na związek między życiem Abrahama i decydującym zwrotem w historii Izraela. A zatem jądro historii Izraela było już obecne w Abrahamie.

Abraham, którego chrześcijańska tradycja pokazuje jako articulum temporis, był przedstawiony w tradycji hebrajskiej jako punkt skupienia przyszłej epoki. Rozpoczyna on nowy czas, ale tylko dlatego, że ten czas jest w nim samym. On jest proroczym znakiem przyszłego życia Izraela, w takim sensie, że jego życie jest proroctwem. Jest w nim obecne

${ }^{45} \mathrm{~S}$. Cavalletti, Il potenziale religioso del bambino. Descrizione di un 'esperienza con bambini da 3 a 6 anni, Roma 2000, s. 165.

${ }^{46}$ Zob. tamże, s. 44. 
to wszystko, co dokona się w przyszłości. Abraham jest żywym znakiem. W nim żyją przyszłe wydarzenia, można powiedzieć, że łączy w sobie swój lud, ponieważ żyje nim, poprzedzając jego doświadczenie.

Relacja między Abrahamem i Izraelem nie ogranicza się do wydarzeń historycznych, które zawierają w sobie religijną wartość, patriarcha i naród znajdują się w tej samej pozycji w stosunku do Boga. Bóg jest obecny i w Abrahamie, i w swoim ludzie. Zarówno Abraham, jak i naród są powołani, wybrani, błogosławieni przez Boga, zjednoczeni przed obliczem Boga ${ }^{47}$. Solidarność historyczna i religijna łączy zatem naród izraelski z ojcem narodu. W tym podobieństwie nie może zabraknąć oczywiście udziału Abrahama w darze Prawa, które jednoczy naród izraelski; nieobecność Abrahama w tym wydarzeniu odcięłaby go od swojego narodu. Kiedy Melchizedek ofiarowuje chleb i wino, odsłania Abrahamowi Prawo.

Takie rozumienie znaków: wydarzeń (np. stworzenie, potop, Pascha) czy jedności między osobami może pomóc w zrozumieniu tego, co mówił Jezus, kiedy porównał siebie do krzewu winnego (J 15, 1-11). Jak czytamy w Starym Testamencie (Ps 80, 9-17; Iz 5, 1-7 i inne), alegoria ta była stosowana właśnie do narodu izraelskiego. Cavalletti widzi w tym pewną ciągłość, dalszy rozwój, ponieważ Mesjasz i Izrael tworząjedność. Porównanie to nie może być rozumiane jako przejęte i dostosowane do Jezusa, ponieważ, jakuczy tradycja, ,skoro Abraham jest typem Mesjasza, zawiera w sobie swój lud, o ile więcej sam Mesjasz może zawierać w sobie swój lud”48. Można tu dodać, że Cavalletti dostrzega, iż „wydarzenia, jak i osoby otrzymują światło z dwóch stron: bezpośrednio z wysoka, jako objawienie Boga, a zatem są z n a ka mi ; horyzontalnie, na ile złączone są z wielkim wydarzeniem historycznym, przyjściem Mesjasza, i wtedy są ty p e m "49. Tak zwane filo d’oro (złota nić) przewija się przez wszystkie wydarzenia historii zbawienia oraz osoby z nią związane, od stworzenia przez odkupienie aż do paruzji. Dziecko wprowadzane w jedność historii zbawienia odnajduje w niej swoje miejsce. Dzięki pamięci w rozumieniu uobecniania staje się uczestnikiem tej historii.

\footnotetext{
${ }^{47}$ Por. tamże.

${ }^{48}$ Tamże, s. 46.

${ }^{49}$ Tamże, s. 50.
} 


\section{Zakończenie}

W proponowanej przez Cavalletti metodzie typologicznej dzieci mają możliwość zbliżenia się do nieskończonej Tajemnicy Boga. „Tajemnica przemawia i działa, a ja dochodzę do niej w słuchaniu i w celebracji sakramentalnej" ${ }^{50}$. Metodą słuchania o historii jest typologia. Przez nią zbliżamy się do Tajemnicy. Natomiast podczas celebrowania, upamiętnienia tejże Tajemnicy stajemy się jej uczestnikami. Przesłanie Boga można uchwycić i żyć nim jedynie w kontekście jedności i całości historii biblijnej, koncentrując się w teraźniejszości na historii przeszłej i przyszłej.

Dziecko powyżej szóstego roku życia jest wprowadzane głębiej w przymierze z Bogiem. To przepowiadanie (przypowieść o dobrym Pasterzu, wychowanie do relacji, otwarcie się na drugiego) zostaje poszerzone o wymiar historyczny. Istotne jest to, że historia w wizji biblijnej jest wszechogarniająca, co oznacza, że dotyczy każdego człowieka, również mnie, staje się moją osobistą historią. W takim znaczeniu dziecko odczytuje historię zbawienia jako urzeczywistnienie się zamierzonego od samego początku przez Boga planu komunii. Tym planem kieruje Bóg, a my znamy cel. Wszystkie wydarzenia połączone są wolą miłości i tworzą całość ${ }^{51}$.

Przedstawione teoretyczne założenia koncepcji Katechezy Dobrego Pasterza autorstwa Sofii Cavalletti mają również swoje przełożenie na praktykę. Oprócz wskazówek metodycznych, w jaki sposób wspólnie z dziećmi odczytywać wybrane teksty biblijne, opracowała ona szereg materiałów do ich osobistej pracy.

Historia i pamięć przekazywane przez Biblię i liturgię wprowadzają nas w inny wymiar rozumienia historii. W każdym wydarzeniu historyczno-biblijnym wierzący człowiek odnajduje swoją historię. Natomiast w celebracji tych wydarzeń dochodzi do ich upamiętnienia, czyli uaktualnienia. W celebracji wydarzeń ma miejsce spotkanie się trzech wymiarów czasu: przeszłe wydarzenie historyczne, antycypacja przyszłej paruzji i uobecnienie ich w teraźniejszości. To wszystko może dokonać się dzięki znakom historycznym i rytualnym.

Kraków

BARBARA SURMA

\footnotetext{
${ }^{50}$ S. Cavalletti, Potencjał duchowy dziecka $w$ wieku od 6 do 12 lat..., dz. cyt., s. 113.

${ }^{51}$ Por. tamże, s. 137.
} 


\section{Słowa kluczowe}

Typologia, znak liturgiczny, pamiątka, Katecheza Dobrego Pasterza

\section{Summary}

\section{History and memory in biblical and liturgical catechesis of Sofia Cavalletti}

The main topic raised in this article is Sofia Cavalletti's idea of religious education, which is closely related to historical message and educates to understanding what memory in liturgy really means.

The aim of the article is to present briefly theoretical basis of the Catechesis of the Good Shepherd for second and third level of religious education (children 6-12 years old). This approach is based on the method of signs and it introduces children to the history and memory of the Chosen People.

First, the author justifies the choice of the method of signs in context of the Judeo-Christian tradition and biblical-liturgical message. The Catechesis of the Good Shepherd in its theoretical and practical message allows to understand history as the past - memory, as well as the anticipation of the future - awaiting of the day of Parousia, which both happen ,here and now".

\section{Keywords}

Typology, liturgical sign, memory, the Catechesis of the Good Shepherd 